\title{
Preparing School Leaders to Interrupt Racism at Various Levels in Educational Systems
}

\author{
Christa Boske \\ Kent State University \\ U.S.A.
}

\begin{abstract}
This narrative inquiry seeks to advance the field of educational leadership preparation by exploring ways to interrupt personal, interpersonal, and institutional racism through the senses-ways in which people perceive their experiences and relation to others. Findings suggest that participants engage in actions aligned with revelations from their reflective process and utilize their positions as a lever to address racism at various levels within educational systems. Participants utilized their transformed storied selves to challenge the disparate impact of power and privilege on educational and social equity within school communities.
\end{abstract}

\section{KEYWORDS: racism, equity, narrative inquiry, leadership, educational}

\author{
Literature Review \\ Method \\ Findings \\ Discussion \\ Recommendations \\ References \\ Author Contact
}

Arne Duncan, the U.S. Secretary of Education, issued a wakeup call for US public schools when he announced, "The undeniable truth is that the everyday education experience for too many Students of Color violates the principle of equity at the heart of the American promise" (U.S. Department of Education, 2012). The announcement was made after the Civil Rights Data Collection shared findings from $72,000 \mathrm{~K}-12$ schools in 7,000 districts serving $85 \%$ of the nation's children. Findings suggest Black students face harsher discipline and experience less rigorous curricula than their White counterparts. In addition, although Black students were only $18 \%$ of the total student population, they accounted for $35 \%$ of suspensions with $46 \%$ of these students experiencing more than one suspension, and 39\% expelled from school. Furthermore, one in five Black boys and more than one in 10 Black girls received out-of-school suspensions. Black students were more than three times as likely to be 
suspended or expelled. The report also examined the school-to-prison pipeline and found that $70 \%$ of students involved in school-related arrests were Black or Latino/a. When considering academic course/program opportunities, only $26 \%$ of Black and Latino/a students were identified as gifted, and only $29 \%$ of high schools with majority Black and/or Latino/a students offered advanced placement math courses (e.g., calculus).

Given these statistics as well as current, historical, and racial resegregation of K-12 public schools in the United States (Hartman, Gerteis, \& Croll, 2009; Orfield \& Lee, 2005), research should examine the existence of cultural and racial inequities. Concurrently, school leadership preparation programs need to critically ground their practices and policies with an emphasis on race and social justice to create proactive strategies that address disparities (see Gooden \& Dantley, 2012). This study investigates how aspiring school leaders addressed personal, interpersonal, and institutional racism through the senses-ways in which people perceive their experiences and relation to others (e.g., Eisner, 1994, 2002; Geurts, 2002).

\section{Literature Review}

Although scholars continue to promote social justice and equity in schools (see Blankstein \& Houston, 2011; Boske, 2012b, 2014a, 2014b; Boske \& Diem, 2012; Boske \& McEnery, 2012; Frattura \& Capper, 2007; Marshall \& Oliva, 2010; Theoharis \& Brooks, 2012; Tooms \& Boske, 2010) and share stories of school leaders who engage in this work (e.g., Marshall \& Anderson, 2008; Shoho, Barnett, \& Tooms, 2011), few studies examine roles of leadership as a lever against institutionalized and structural oppression (see Brooks, 2012). The term "oppression," when examining the racial state of affairs in schools, suggests a link between those who are oppressed and those who oppress. In a racialized society, there are oppressors and the oppressed, just as there are exploiters and the exploited (Marx \& Engels, 1964). This understanding suggests a social relationship favoring oppressors. One means of countering oppression is promoting use of transformative curriculum (e.g., Boske, 2014a, 2014b; Brown, 2004; Marshall \& Oliva, 2010).

The concept of transformative curriculum suggests a need for a broadbased and systemic reform in school leadership preparation to increase critical consciousness (e.g., Brown, 2004, 2006) as well as a totality of reflection and action from the leader who wishes to change it (Freire, 2000; Kaak, 2011). This requires a deeper and more comprehensive curriculum analysis (Burns, 1978; Eisner, 1994; Noddings, 1984) and actions necessary to interrupt oppressive school practices (Bogotch \& Shields, 2014; Marshall \& Oliva, 2010). Preparing school leaders to utilize their positions to address racism, equity, and access speaks to core questions that remain central to curriculum studies (e.g., Kridel, 2010; Malewski, 2009), especially sensory curriculum (Boske, 2012a, 2012c), as 
well as school leadership preparation (e.g., Brooks, 2012; Marshall \& Oliva, 2010).

A sensory curriculum (e.g., Cahnmann-Taylor \& Siegesmund, 2008; Ellsworth, 2005; Erlmann, 2010; Howes, 2005; Menon; 2010; Ranciere, 2010) emphasizes expansive understanding of self, including the arts (e.g., poetry, video, music, visual arts, and dance). There is a need to make sense and develop an understanding of who we are in relationship to the world (Boske, 2014a; Greene, 2004; Pinar, 1988). One means of understanding how learners make sense is to provide them with opportunities to move beyond themselves, search for imaginative possibilities, create possible alternatives, and utilize new embodied ways of knowing to counter other stories to empower and re-create a common world (Boske, 2014a, 2014b; Greene, 1988; Pinar, 2011). A sensory curriculum may provide school leaders with spaces to reconceptualize themselves and relation of self to others in an effort to make systemic change through new storied selves (e.g., Boske, 2014a, 2014b; 2012a, 2012c; Greene, 2004; Dewey, 1934, 1938, 1961; Gershon, 2010; Pinar, 1988, 2011).

There is a need to better understand how school leaders may utilize the senses to become social actors to enact what they learn-negotiate meaning through educational contexts, local understandings, interpersonal interactions, and sociocultural contexts (see Boske, 2014a, 2014b; Brown, 2004, 2006). These micro and macro interactions may influence school leaders' values, decision-making, and daily lives. A sensory curriculum considers how school leaders come to understand their sense of self through the influence of personal knowing and being, both in and out of formal, institutionalized contexts, such as districts, schools, and classrooms (see Boske, 2014a, 2012a, 2012c; Kridel, 2010). Such examinations may include artistic processes (e.g., CahnmannTaylor \& Siegesmund, 2008; Leavy, 2009) and sound as meaning (Gershon, 2012), as well as considering the intersections of space, place and identity (Ellsworth, 2005; Kincheloe \& Pinar, 1991).

\section{Method}

The research method employed was narrative inquiry (Clandinin \& Connelly, 2000), which is the most appropriate methodological approach because I was investigating meanings of experiences. Attending to experience through inquiry is what distinguishes narrative inquiry from other methodologies (Clandinin \& Rosiek, 2007; Clandinin \& Connelly, 2000). It is a way of thinking about and studying people's experiences through starting points in telling and living their histories (Connelly \& Clandinin, 2006) as well as social and personal contexts (Bruner, 2004; Connelly \& Clandinin, 1990). Narrative research is an upclose and personal methodology in that it involves in-depth study of particular individuals in social context and in time, requiring a highly sensitized and selfreflective inquirer versus a set of objective impersonal skills (Josselson, 2003). 
Narrative inquiry is a human experience approach affording researchers opportunities to develop interpersonal relationships within the context of the study. The use of narrative also provides analytic themes and fieldnote excerpts throughout the study (Creswell, 1998). Narrative inquiry contends that the educator's knowledge is founded on social and personal contexts (Bruner, 2004; Connelly \& Clandinin, 1990). The notion of personal knowledge reflects the interactions of prior knowledge and the contextual nature in which this knowledge has been acquired (Clandinin \& Connelly, 2000). Participant experience is best represented and understood through their personal stories or narratives (Connelly \& Clandinin, 2000).

While the approach has potential to reveal many nuances involved within the woven tapestry of a story, narrative inquiry is not without its tensions. Through my practitioner research as a narrative inquirer, I sought to dismantle the authority vested in me. I realized that my role as researcher could be threatening for participants who were more familiar with positioning professors as authority figures. After receiving Institutional Review Board (IRB) approval, graduate students were invited to participate after completing their coursework; I did not want participants to associate their grades with their willingness to engage in the study. Two graduate students chose not to participate, because they did not believe that their international perspectives were relevant to leading U.S. K-12 public schools. I believe my efforts were inclusive due to the conceptualizations of the university-school relationship established at the beginning of our work, which may have lowered participants' anxiety. Kim (2008) navigated tensions involved in narrative inquiry and identified one of its problematic issues-namely, its inherent narcissism. As a researcher, I sought to stay away from the tendency to place emphasis on my perceptions, to avoid what some researchers refer to as nouveau solipsism. Hatch and Wisniewski (1995) suggest a strong tendency among scholars to reflect on their work and their place in it rather than to do the work. Elbaz-Luwisch (2007) also posited that "although narrative inquiry has already made a significant contribution to the development of... public language... narrative inquiry, indeed, confronts a range of problems resulting from the difficulty of presenting a complex, layered, and dynamic reality" (p. 253).

\section{Participants}

This study included 98 participants (i.e., 9 curriculum coordinators, 11 principals, 6 assistant principals/deans, and 72 teachers) enrolled in Leading for Social Justice, the first of two required graduate courses as part of a degree program at a Midwestern university. There were 56 master's level, 21 Ed.S., and 20 Ph.D. participants. All but 11 graduate students were working towards earning their principal, superintendent, and/or educational specialist license. The racial backgrounds of the participants included: Black (22), Latino/a (8), Middle Eastern (10), Eastern Indian (1), Asian (5), biracial (one-Black and American Indian), and 
White (51). Eighty-seven identified themselves as native English speakers, four as Chinese, and seven as Arabic. All of the participants identified themselves as heterosexual. Eighty participants were raised in middle and upper class communities and 18 in lower class communities. Ninety participants considered themselves to be able-bodied and able-minded, while eight identified themselves as having a learning difference while attending $\mathrm{K}-12$ schools. All of the participants noted living in middle-to-upper class communities as adults. Thirtyfour participants were single, 63 were married, and one was living with a significant other.

\section{Data Collection}

Data for this study included 98 equity audits (see Frattura \& Capper, 2007; Skrla, McKenzie, \& Scheurich, 2009) conducted in K-12 U.S. schools, 997 audio and video reflections (15-45 minutes per reflection), 294 written narratives, 98 art abstracts/projects, and 46 classroom/field observations. These participants were part of an educational leadership program aimed to engage them in sensory reflective practices regarding (a) how they perceived themselves as leaders; (b) how these contexts informed those understandings of self in relation to others; and (c) to what extent these understandings influenced their daily interactions. Participants contextualized their daily interactions, identified the extent they negotiated their identity within these spaces and places (i.e., private and public lives), and reflected on the flux of daily interactions and extent of nested meanings emerging throughout their learning.

Participants engaged in critical reflection (e.g., Mezirow, 1990; Schön, 1983; Terrell \& Lindsey, 2009) via written/audio/video entries (Boske, 2012a, 2012c, equity audits (see Frattura \& Capper, 2007; Skrla, McKenzie, \& Scheurich, 2009), and art-making (see Springgay, 2008) as experiential modes of sensory curriculum inquiry to examine how they understood racism through the senses (e.g., sight, sound, and visual). Reflective questions focused on how participants understood identity, values, beliefs, decision-making, power, privilege, school policies/practices, and institutionalized behaviors and how these were used to encourage self-critique and reconceptualization of self (see Delpit, 2002; Gay, 2010; Lindsey, Roberts, \& Campbelljones, 2005; Nieto, 2000). Equity audits were conducted in 96 public schools and two private Christian schools.

\section{Data Analysis}

I analyzed data using a constant comparative method, comparing one incident or section of the data (transcripts, field notes, and observations) with other sections in the same or different data set (Merriam, 1998). All interactions were transcribed and coded (Miles \& Huberman, 1984). I began by looking at the 
data that resulted in discovering major themes for the study (Lincoln \& Guba, 1985). The emerging of themes created an integrated story line. For each round of data analyzed, field notes were compiled from audio/video reflections, written narratives, and observations. Systematically filtering large volumes of data was a useful technique for discovery and in-depth analysis of participants' thoughts/ experiences (Glesne, 2006; Weber, 1990). This led me to trends and patterns within the data (Connelly \& Clandinin, 1990; Glesne, 2006).

\section{Findings}

Participants' notion of making sense centered on deepening their understanding of racism at various levels within the educational system (i.e., self, school/district, society). Utilizing the senses often provided opportunities to align their actions with revelations within their coursework. Participants stressed their deepened understanding of the emotion-laden process of internalizing new ways of knowing and addressing racism in schools (Langer, 1953). Emerging themes include (a) an increased critical consciousness; (b) making connections between personal knowings and new storied selves; and (c) taking action.

\section{Increased Critical Consciousness}

Participants examined their ability to decipher the influence of social, political, and economic oppression in K-12 schools (see Freire, 2000). The audio/video/written narrative process, critical dialogue with peers/school community members, connecting theory to practice, and actively engaging in equity audits provided opportunities for participants to increase their critical consciousness. Participants recognized throughout their audio/video reflections how often they promoted past school practices rather than deepening their understanding regarding alignment among practice, policy, and ways of knowing.

Initially, all of the White participants said they lived in a racially desegregated society. Forty-five White participants suggested the symbolic and historical presidency of President Obama and living in a post-Civil Rights race era supported their belief that racism did not exist in the United States. These participants initially placed blame on children of color for schools not meeting/exceeding standards, low enrollment in advanced placement/gifted programs, increased student discipline, and low community/family involvement. Seventy-eight participants identified children of color, specifically Black children as "unmotivated," "lazy," or "not able to learn at the same level as White children." Susan, an elementary teacher, clarified her increased awareness during an audio reflection:

Admitting to myself I was one of "those" teachers...the ones who believe deep down inside that Black students don't have the same ability to learn 
as White students... was difficult to handle...but it all came out... no worries about what I was going to say or grammar...it just came out on those damn videos and I knew I couldn't and shouldn't delete it...I struggled with trying to evolve into this new self....

After being asked to reflect on the intersections of their identity and decision-making in schools, 43 participants realized their role in perpetuating oppressive practices for children of color in schools. These participants shifted from identifying themselves as "saviors," to "oppressors" and then ultimately to educators in positions of power to "do something." Casey, a high school principal, served as an example through a quote from her audio reflection:

I moved from thinking I was this White savior to being ashamed of myself for thinking this way...I didn't worry about what I was writing or sentence structure...I spent time realizing I am in a position of power as a White, upper class, heterosexual, married with children principal... who could interrupt the deficit dialogue and share what I learned about myself with the teachers I work with....

Eighty-five participants emphasized the need for spaces to think critically about how their teacher preparation programs, teacher evaluations, professional organization national/state conferences, and/or professional development did not afford them with opportunities to think about the influence of social, political, or economic factors in schooling children. All of the participants of color stressed the need for school communities, curriculums, and professional development to address racism. Forty-nine White middle class participants noted in their written, audio/video, artmaking, and equity audit reflections that they did not initially understand conditions facing students of color and stressed the role they played in perpetuating racialized practices and policies. For example, James, a White, male, middle class teacher, noted in an audio reflection regarding his artmaking, "We don't talk about this at work or in professional development, but I know now it's needed, because we can't ignore the pink elephant in the room...racism is toxic and silent in my district." Joanne, a 15-year White veteran lead teacher in an affluent suburban school district, shared her new understanding in an audio reflection:

If there is one thing I learned that has resonated with me is the power of reflecting on the things that make me most uncomfortable...and race is definitely one of them. Digitally recording my thoughts...committing to translating my thoughts into artmaking...digital shorts about my experiences....afforded me spaces in which I didn't think about grammar or saying the right thing...it was uncomfortable at first... The space to think freely helps me learn to listen to myself...to feel, to watch myself and others more closely.

Forty-three White middle class participants initially shared how often they referred to children of color as "those kids" and identified themselves as "saving" marginalized populations through their work within "these" public schools. Fortyseven White, middle class participants realized efforts to promote "global 
classrooms" in US schools should not center on higher standardized test scores; rather, their efforts stressed the need for K-12 educators, school leaders, and students to develop a critical consciousness regarding oppressed populations across the globe. For example, Martin, a White male high school leader, noted in a video reflection, "We don't often take time to think about this... video allowed me to feel free to reflect on the loss of democracy...human rights...the need for solidarity among disenfranchised populations....and the need for allies to use their power and privilege to interrupt an age of repression...no boundaries...no restrictions... I found myself deepening my understanding of who I was...I didn't like it...I was ashamed....and who I want to become."

Eighty-four participants (49 White, 22 Black, 8 Latino/a, and 5 Asian) recognized the need to expect from themselves what they hoped for from the children and communities they served. These participants stressed the need to examine their own identities, to think critically about their personal/professional/organizational interventions, and to interrupt oppressive practices and policies versus adapting to them. They identified the reflective process, critical dialogue with school community members, and equity audits as essential components to increasing their critical consciousness. Joseph, a White principal who grew up in an upper class community, noted in a video reflection, "Video recording my thoughts was scary. It was uncomfortable. I couldn't hide behind a typed word. I was out there. I was vulnerable and learned to be present with myself and my real thoughts." Amanda, a biracial department chair raised in a lower class community, explained in her audio reflection:

This is uncharted territory. I had to face who I was ...I discovered a passion inside.... a fire in my belly...I could see it, hear it, and feel it... I thought critically about my connection with others, within society, across nations, and within or among group histories... I investigated the inner workings of my development and used this understanding for committing myself to the next step.... openly denouncing oppressive practices and policies in schools...I moved from not knowing to deepening my ways of knowing to examining why I came to be who I am to denouncing cultural deficit practices to immersing myself in ways to counteract them. I witnessed the transformation in my voice, my body language...I changed...emotionally stronger, insightful, and realizing how to use my position as a graduate student as power...to share ideas...to jump in conversations that were toxic and interrupt them.

Eighty-seven participants in this study concluded that their schools did not encourage educators, students, or families to think critically about race and racialized practices. Ninety-five participants stressed the need for a concerted effort in teacher preparation, district professional development opportunities, or national/state professional conferences to consider the plight of marginalized students and families, especially students of color. Michael, a central office school leader, noted during a classroom discussion: 
I realize I never stopped to think about race or racism, because I didn't need to...it's shameful to say, but I only thought of things if I was the person who had to deal with them...I could hear this in my voice...soft, deep, raspy.... silences had new meanings...it's hard to talk about this, because now I know, and now I have no excuse not to address these oppressive practices and policies in schools.

Another participant, Dyann, a middle school White teacher, concluded in an audio reflection, "There is an urgency within me that did not exist before...I hear it in my tendency to speak faster...with passion...emotion...l was in the unknown...the silences grew...uncomfortable enough to understand the need to awaken myself and others to what's happening in schools to our Black and Brown children." And Desmond, a Black assistant principal, noted in his equity audit becoming more aware of physiological changes throughout the process, "Standing still is no longer an option....it's been one hell of journey... stomach upset, heart beating faster when I think about all of this...tension inside about to burst...I can't sit here and watch this happen to our children, especially our Communities of Color."

Forty-eight White middle class participants shifted from being unaware to having more awareness of ongoing and oppressive practices and policies in schools, especially for children of color. Forty-five of these participants noted they made connections between theory and their work in schools through sensory activities (i.e., video/audio reflections, digital shorts, and artmaking). Quincy, the first Black school leader hired in a predominantly Black school district, emphasized in a written narrative, "Reading Bogotch and Marshall's work was just the starting point along this unbeaten path. I saw and felt my new sense of responsibility. I found a place encouraging me to follow my commitment to address racism in my school." Margaret, a White middle class elementary team leader, also noted in an audio reflection, "I was evolving...it was transformative.... a new self...I was so uncomfortable, because I didn't like what I saw on the screen or what I caught myself saying out loud. The process helped me see what others saw...ugh...I needed to change." Angela, a White high school teacher, explained how these spaces influenced her understanding of self-reflection:

I needed this space...not to write... but to be...just be...because using text dictated what was perceived as the right thing to say. When I spoke freely, I looked deeper into where I was, who I was becoming, and wanted to take the leap to do something about the injustices I witnessed.

Forty-eight White middle class, 18 Black middle class, and five Latino/a middle class participants questioned prior practices as well as information presented to them in texts, workshops, and professional contexts. These participants discussed the need to interrupt their oppressive thoughts, dialogue, and actions by becoming more aware of personal bias. Fred, a White suburban teacher leader, emphasized in his equity audit reflection, "I want to know my blind spots...I want to be in the know about myself, because I don't want to be the 
oppressor I unintentionally became." Jonathan, a Black middle school teacher, examined his new self-awareness.

As an educator, I never discussed racialized speech or culturally responsive educational practices. Now, I question why we do what we do and discuss and realize my professors didn't have a clue about Critical Race Theory or Whiteness Studies...reforming myself was first and foremost...creating a new story.

There was a concerted effort by White middle- and upper class participants to consciously understand why they engaged in specific oppressive practices and upheld school policies. These participants did not initially recognize racial oppression as a structural problem and understand how schools tended to perpetuate race-based practices. Roseanne, an assistant principal, reflected: "We often criticize, blame, and isolate Black students and families. We don't think about the damage we do and the role we play in perpetuating this." Forty-eight White middle class participants emphasized placing the emergence of cultural responsiveness on their own shoulders. For example, Bill, a department chair, concluded in his equity audit reflection:

We needed to allow ourselves spaces like this... for our subconscious and new conscious to collide...it's a new story ...I never thought about the power of seeing, hearing, feeling, and being...together...to make sense out of all of this....what a journey!

In summary, most White middle- and upper class school leaders and teachers revealed tensions between what they previously believed and their newly lived experiences to address racism at a personal level. These participants identified as oppressors, discussed their discomfort with the process of deepening their understanding of self, and shared their anxiety as they engaged in what several identified as "uncharted territory." People of color, however, expressed a need to increase awareness and critical dialogue within school communities and preparation programs in order to interrupt deficit thinking.

\section{Connections Between New Ways of Knowing and Creating New Storied Selves}

Eighty-nine participants in this study identified reflective processes as ways to reconsider how their experiences, beliefs, and ways of knowing influence the reconstruction of self and their role in addressing racism at various levels in schools. Sarah, a Black elementary teacher, stressed the significance of using video for self-reflection, "Unbelievable...the process shed light on connections between what I think, believe and do...I could see it...it's multiple layers of my life...a new me...a new story...how one impacts the others...coming together...building on another." Janet, a Latina team leader, also argued of the importance for self-reflection in using the senses: 
It's the opportunity to discover and do the work...the work we do on ourselves and with schools...engaging in this process.... it changes you...the experiences give you the space to explore who you are... who you are becoming... and realize the real work is using this new me in the doing....

Lynn, a Latina high school teacher, also noted in her audio reflection the process of creating a new storied self, "The process was like no other...I made authentic connections between what I was thinking and what I needed to do...there were lots of layers to this...it was a new story of who I was and who I was becoming by... creating new social and political spaces for students, families, community members, and educators

These eighty-nine participants expressed an urgency to make connections between their new understandings and creating a new storied self. Twenty-two of these participants emphasized the need to deepen their understanding of self in order to better understand how they made meaning from their experiences with Students and Communities of Color. Rollin, a Black male elementary teacher, discussed in his equity audit reflection the need to "open both eyes" versus "keeping one eye closed" and to "awaken" himself to racialized practices:

This is such an emotional process. Eyes wide open and thoughts free flowing...video, audio, artmaking, equity audit. The process is filled with tension... there is a sense of urgency that evolves... we learn we are multilayered...the experiences we gain....the role we play.... examining how we think, why we think the way we do...a new story of who I am emerges.

These same participants stressed how they utilized their personal knowing to consider their role in addressing racialized social systems embedded throughout their decision-making in schools. Tyann, a curriculum leader, explained in a video reflection how sense making helped her make connections between her critical consciousness and new storied self

I feel and live what I am learning... it is like the trapeze artist letting go, seeing the bar, hoping to grab onto the next bar... to live what I have come to understand... and making it part of my new story...to immerse my new self... play an active role in promoting an institutional culture that empowers all school community members, not just the White ones.

Thirty-eight White middle class participants discussed how they know they increased their critical consciousness and created a new storied self. Sabastian, a middle school lead teacher, said in an audio reflection, "I can't believe how often I hear 'those' kids now... and how often we........blamed children and their families for the societal ills... it sickens me now...I took what I learned, became aware, looked through a new lens, and made this understanding a new part of my story." These participants came to recognize new connections between personal awareness, data, decisions made, and who they are as school leaders. Robert, an elementary teacher, demonstrated his newfound awareness: 
We are often afraid of Black children, especially young Black boys and then we jump to conclusions...never thinking about how one aspect of this equation is related to the next. This new awareness has become part of who I am now, my new story, and hopefully, I will keep growing as a school leader....

Frances, a department chair, concluded in his video reflection, "I realized how often I used language such as 'subgroups' and 'those kids'... it signified they were below the norm or outliers...and then we treated them accordingly. I took what I learned about myself, evolved into something new, and used my new understanding to interrupt this deficit-laden language in my head." There was also the need to interrupt this demoralizing language" in schools towards Children and Communities of Color by using data. Rachel, a middle school teacher, considered the impact of her exchanges:

How often I contribute to the racial microaggressions experienced by my children. I am realizing their compound effect.... I have a strong conviction to wake up myself and my colleagues to the everydayness of racism and to the transparency of racism....we are not in a post-Civil Rights era.... am learning how to collect data to help my White colleagues understand the complexities of racism...to address this complex and emotional ridden topic...to provide my peers with new ways of thinking about race. I am coming to understand my new self and how to use my new self as a force to counter these oppressive ways.

All participants emphasized the power of examining personal knowing in reconceptualizing their new understandings of self. These new understandings influenced their awareness and capacity to address racialized school practices and policies. Anna, an elementary teacher, summarized the connection between her newfound knowledge and educator peers:

There is need for the new me to counter these oppressive stories by interrupting the majority's line of thinking about our Brown and Black children.... I share what I am learning about myself with my peers at work...I say something now...sometimes they look at me strange, like, "Who is that?"

In summary, these White middle class participants recognized challenges to act independently within racialized institutions. One means of countering or rewriting institutional racial narratives through their new storied selves was to contextualize the pervasive racism in schools and unsettle common school practices through their equity data collection, analysis, sharing of findings, and promoting action plans. Efforts to look within and make connections between their new understandings and storied selves to interrupt school practices did not ensure new views on racism throughout their school communities; however, their new personal knowing and willingness to interrupt oppressive practices played a critical role in their ability to take action (i.e., making connections between their reflections and practices, collecting data regarding oppressive school practices, and analyzing and sharing equity audit data). 


\section{Taking Action}

Eighty-nine participants concluded they had a responsibility to utilize their new personal knowings to address racism at various levels with the educational system. For these participants, understanding shifted from being unaware of racism in schools, to deepening their understanding, to doing something to address racialized practices and policies. These participants utilized findings from their equity audits, audio/video reflections, artmaking, and positions in schools (i.e., informal and formal leaders' positions) to promote change. Michael, a Black principal who grew up in a lower class community, clarified:

It's about making small steps during a long journey. I addressed disparities facing our young Black males who end up in special education more often than White students...facilitating professional development with interested teachers, bringing it together in my art with over a thousand community members, revising curriculum, and creating youth leadership teams for Brown and Black students.

Many of these participants stressed a need for deliberate counteracts in schools to interrupt racism at various levels. These included curriculum, pedagogy, discipline, special education, and school policies. Kim, a White middle class teacher leader, explained in her audio reflection, "I did something with their voices (findings from her equity audit)....I incorporated the lives of People of Color in student learning in science, social studies, and language arts, and cocreated a three-year action plan to continue this work in our team and faculty meetings." Janet, a Latina team leader, discussed the significance of translating her new understanding into action in her video reflection, "I used the 'new' (made quotation marks with her fingers around her head) me in actually doing this work. I addressed discipline disparities between our Brown/Black children and White children by implementing something new...curriculum that considered the strengths of our Brown and Black students as well as their families."

These participants regarded their efforts to make sense of their new lived experiences (i.e., self-reflection, new understandings, artmaking, facilitating critical dialogue with school community members about equity in schools, collecting data, analyzing findings, proposing research-based solutions, and cocreating actions plans to address inequities in school practices and policies with school community members) as a deliberate force to counter racial oppression. Tyrone, a Black teacher who grew up in a middle class community, explained in his audio reflection how he became a formidable force in the lives of Students of Color:

I became an ally, an advocate, a tempered radical.... I used my audio, video, music, silence and art as activism... rapping in my videos, writing poems...creating purposeful silences to get people uncomfortable... bringing it all together in creating and sharing my school-to-prison pipeline art piece to hundreds of people in the Leading for Social Justice art 
exhibit.... presented disparities facing our Brown and Black students to all teachers.... promoted the need to use a strengths perspective in my school district. Because of this, some of us are doing home visits, revising our curriculum to include race, and talking about how our beliefs influence what we do throughout faculty meetings.

Many of these participants found themselves in similar situations. Demetri, a Black principal who grew up in a lower class community, discussed how he challenged the views and miseducation of young Black males:

I came to a new understanding and sense of responsibility through this process...seeing, listening, artmaking, dialogue, reflecting....pushing myself to think beyond what I thought was possible I changed school policy so every incoming student will take Algebra...no more remedial math for our students (99\% Black). There was resistance from White teachers, but I used my whole self...to promote what I know is just during faculty meetings, and openly addressed issues of race for the first time in our building.

Most of these participants stressed how the reflective process afforded opportunities to create school practices and policies that bridge individuals and school communities to promote equity, especially for children and communities of color. As Olivia, a White middle class elementary teacher, emphasized in her equity audit, "The process was a dance...a back and forth.... promoted the power of 'we' through my new 'me'... it's how my story influences what I do now.... changed an entire grade level curriculum to incorporate issues of race and for the first time, talked about White privilege, institutionalized racism, and issues of race facing our students and families in our professional learning at the building and district levels."

For these participants, considering historical context and the need for interdisciplinary perspectives was essential. Mandy, a White middle school team leader raised in an upper class community, stressed in her equity audit, "We perpetuated racism by allowing our Black males to continuously fail math courses. I addressed these disparities head on in dialogue (about race) with my team, actually changing our practices through pilot studies, and revising curriculum. I internalized what I learned and acted on it." Others noted this change in self in a myriad of ways. Participants identified themselves as risktakers (22), visionaries (12), educational reformers (15), revolutionaries (18), and tempered radicals (9) as they reflected on how they understood their role in interrupting racism in schools.

Forty-eight White participants perceived their actions as "small victories." These "victories" were often signs of "progress" and "hope." Although their "small victories" did not eliminate racial institutionalized practices and policies, their efforts often interrupted such practices and policies. For 24 people of color, their struggles became a sign of hope along a "long journey" within their communities of color. Most importantly, all participants emphasized how their new ways of responding to issues of race were felt and lived. 


\section{Discussion}

Participants' new understandings often evolved into new storied selves. These new storied selves were multilayered experiences as they reconceptualized themselves as school leaders to better understand and respond to issues of race (Greene, 2004; Pinar, 1988, 2011). They examined relationships among their new consciousness, school community, and institutionalized racial practices. Many realized how they perpetuated oppressive school practices (e.g., increased discipline and special education referrals for children of color) and reconceptualized themselves as school leaders to position themselves as educational interventions.

Understanding shifted from being unaware to internalizing new personal knowing as a means of addressing racialized practices and policies. These multilayered experiences (i.e., reflections, collecting data, and engaging with school community members) created opportunities for one experience to build upon the next, thus creating a new sense of self as a school leader or storied self. Many reported utilizing their new storied self to promote inclusive practices and policies stressing the strengths and experiences of Students and communities of color. They strived to examine, critique, and promote new school practices in the pursuit of creating new social and political spaces in schools for students, families, community members, and educators, especially for students and communities of color.

Most participants reconsidered how their new storied selves interrupted racism at various levels within educational systems (see Allen, 1995). The sensual process provided a constant exchange of knowing and not knowing through their personal storytelling (see Barone, 2002). Many became more comfortable examining the intersections of their personal and situational experiences. Examinations often encouraged continuous reflection on connections among personal knowing, embodied experiences, and responsiveness.

Understanding the impact of the senses was one pathway to increasing critical consciousness, as well as identifying the implications of institutionalized racial practice and policies (Boske, 2011a, 2011b, 2012a, 2012c; Brown, 2004, 2006). Many participants emphasized how moving beyond text afforded them with spaces to "think freely" and "openly" without "borders or boundaries" in which "silence had meaning." Findings suggest the senses should not be constituted as a completely independent domain of experience; rather, the senses interact with each other in different combinations and hierarchies, not from a purely physical and personal psychological perspective, but as sensations shaped by participants' personal knowing (see Eisner, 2002; Gershon, 2010). Several participants stressed how their new embodied ways of knowing were "lived and felt." Their sense making was influenced through sight, sound, action, reflecting, dialogue with self and others, and artmaking. Making sense of their world played an integral role in understanding how to imagine, create, and 
implement their new storied selves to improve learning for Children of Color in their school communities (see Greene, 2004; Pinar, 1988, 2011). The complex integration of this sensual curriculum created spaces to critically question and interpret common sense notions of school leadership while emphasizing the need to deepen understanding of embodied experiences (e.g., Boske, 2014a; 2014b; Ellsworth, 2005; Greene, 2004; Pinar, 1988, 2011). To a greater or lesser extent, every domain of sensory experience, from sight to sound to touch, influenced how they felt and lived their evolving cultural expression of self as a school leader. For many, their new storied selves were critical to interrupting personal, interpersonal, and institutional racism in schools. They came to understand their leadership roles as a moral obligation to make authentic connections between their personal knowing and urgency for collective action to address racialization in schools.

\section{Recommendations}

As the idea of the sensory curriculum makes its way across social sciences, curriculum studies and other disciplines (e.g., Cahnmann-Taylor \& Siegesmund, 2008; Ellsworth, 2005; Erlmann, 2010; Howes, 2005; Menon; 2010; Ranciere, 2010), there are opportunities for the field of educational leadership to give explicit attention to the senses in understanding embodied ways of knowing. Faculty who prepare school leaders may create broad-based and systemic curricula to encourage activist-oriented responses (e.g., Boske, 2014a, 2014b, 2011a, 2011b; Brown, 2006; Kaak, 2011). A sensory curriculum has the capacity to address racialized institutional practices and policies by providing school leaders with spaces to reconceptualize themselves and relation of self to others in an effort for systemic change (e.g., Boske, 2014a, 2014b, 2011a, 2011b; Dewey, 1934, 1938, 1961).

Such efforts encourage those who prepare school leaders to consider an intersensory transformative curriculum, which explores how the senses interact with each other in different combinations and hierarchies (see Howes, 2003). This reform requires a deeper and more comprehensive analysis of the senses in understanding self with a focus on increasing consciousness, meaning-making, and embodied experiences (Boske, 2011; Burns, 1978; Eisner, 1994; Noddings, 1984). Faculty may consider an expansive understanding of intersensory curriculum by including the arts (e.g., poetry, creative writing, photography, painting, theatre, film, dance, music, collage, as well as other artistic forms) (Boske, 2011a, 2011b; Eisner, 2002), sound (e.g., Boske, 2011a; Friend, Caruthers, \& McCarther, 2009; Gershon, 2010), digital shorts/video (Boske, 2012a, 2011b), and space and place as meaning (Ellsworth, 2005).

All human experiences are essential to interpretation of the senses (Eisner, 1994, 2002; Ellsworth, 2005; Geurts, 2002). The meanings constructed through the senses are interwoven layers of embodied experiences influenced by sociocultural norms and values (e.g., Boske, 2014a, 2014b; Springgay, 2008). An 
intersensory transformative curriculum has the capacity to afford school leaders with spaces to challenge personal knowing in an effort to embody new storied selves. Attending to the sensorium, which embeds the senses throughout learning, may encourage connectedness among self and others and, ultimately, provide spaces to promote equity in schools.

\section{References}

Allen, P. B. (1995). Art is a way of knowing. Boston, MA: Shambhala Publications.

Barone, T. (2002). From genre blurring to audience blending: Reflections on the field emanating from an ethnodrama. Anthropology and Education Quarterly, 33(2), 255-267.

Blankstein, A. M., \& Houston, P. D. (2011). Leadership for social justice and democracy in our schools. Thousand Oaks, CA: Corwin.

Bogotch, I., \& Shields, C. M. (2014). International handbook of educational leadership and social (in)justice. Amsterdam, The Netherlands: Springer.

Boske, C. (2011a). Audio and video reflections to promote social justice. Multicultural Education \& Technology Journal, 5(1), 70-85.

Boske, C. (2011b). Sense-making reflective practice: Preparing school leaders for non-text-based understandings. Journal of Curriculum Theorizing, 27(2), 82-100.Boske, C. (2012a). Aspiring school leaders addressing social justice through artmaking. Journal of School Leadership, 22(1), 116146.

Boske, C. (2012b). Educational leadership: Building bridges among ideas, schools and nations. Charlotte, NC: Information Age Publishing.

Boske, C. (2012c). Sending forth tiny ripples of hope that build the mightiest of currents: Understanding how to prepare school leaders to interrupt oppressive school practices. Planning and Changing, 43(1-2), 183-197.

Boske, C. (2014a). Critical reflective practices: Connecting to social justice. In I. Bogotch \& C. Shields (Eds.), International Handbook of Social [In] Justice and Educational Leadership (pp. 289-308). Amsterdam, The Netherlands: Springer.

Boske, C. (2014b). Using the senses in reflective practice to prepare women for transforming their learning spaces. In W. Sherman \& K. Mansfield (Eds.), Women interrupting, disrupting, and revolutionizing educational policy and practice (pp. 225-253). Charlotte, NC: Information Age Publishing.

Boske, C., \& Diem, S. (2012). Global leadership for social justice: Taking it from the field to practice. Bingley, UK: Emerald Publishing. 
Boske, C., \& McEnery, L. (2012). Catalysts: Assistant principals who lead for social justice. In A. R. Shoho, B. G. Barnett, \& A. K. Tooms (Eds.), Examining the assistant principalship: New puzzles and perennial challenges for the $21^{\text {st }}$ (pp. 125-152). Charlotte, NC: Information Age Publishing.

Brooks, J. S. (2012). Black school white school: Racism and educational (mis) leadership. New York, NY: Teachers College Press.

Brown, K. (2004). Leadership for social justice and equity: Weaving a transformative framework and pedagogy. Educational Administration Quarterly, 40(1), 79-110.

Brown, K. (2006). Leadership for social justice and equity: Evaluating a transformative framework and andragogy. Educational Administration Quarterly, 42(5), 700-745.

Bruner, J. (2004). Life as narrative. Social Research, 71(3), 691-710.

Burns, J. M. (1978). Leadership. New York, NY: Harper \& Row.

Cahnmann-Taylor, M., \& Siegesmund, R. (2008). Arts-based research in education: Foundations for practice. New York, NY: Routledge.

Clandinin, D. J., \& Connelly, F. M. (2000). Narrative inquiry: Experience and story in qualitative research. San Francisco, CA: Jossey-Bass.

Clandinin, D. J., \& Rosiek, J. (2007). Mapping a landscape of narrative inquiry:Borderland spaces and tensions. In D. J. Clandinin (Ed.), Handbook of narrative inquiry: Mapping a methodology (pp. 35-75). Thousand Oaks, CA: Sage Publications.

Connelly, F. M., \& Clandinin, D. J., (2006). Narrative inquiry. In Green, J., Camilli, G. \& Elmore, P. (eds.), Handbook of complementary methods in education Research (pp. 375-385). Mahwah, NJ: Lawrence Erlbaum.

Connelly, F. M., \& Clandinin, D. J. (1990). Stories of experience and narrative inquiry. Educational Researcher, 19(5), 2-14.

Creswell, J. W. (1998). Qualitative inquiry and research design: Choosing among five traditions. London, UK: Sage.

Delpit, L. (2002). The skin that we speak. New York, NY: The New Press.

Dewey, J. (1934). Art as experience. Toms River, NJ: Capricorn Books.

Dewey, J. (1938). Experience and education. New York, NY: Collier Books.

Dewey, J. (1961). Democracy and education. Old Tappan, NJ: Macmillan.

Eisner, E. (1994). The educational imagination: On the design and evaluation of school programs ( $3^{\text {rd }}$ ed.). New York, NY: Macmillan.

Eisner, E. (2002). The arts and a creation of mind. New Haven, CT: Yale University Press. 
Elbaz-Luwisch, F. (2007). Studying teachers' lives and experience: Narrative inquiry into K-12 teaching. In D. J. Clandinin (Ed.), Handbook of narrative inquiry: Mapping a methodology (pp. 357-382). Thousand Oaks, CA: Sage.

Ellsworth, E. A. (2005). Places of learning: Media, architecture, pedagogy. New York, NY: Routledge Falmer.

Erlmann, V. (2010). Reason and resonance: A history of modern aurality. Cambridge, MA: Zone Books.

Frattura, E. M., \& Capper, C. A. (2007). Leading for social justice: Transforming schools for all learners. Thousand Oaks, CA: Corwin.

Freire, P. (2000) Pedagogy of the oppressed. New York, NY: Continuum.

Friend, K., Caruthers, S. M., \& McCarther, S. M. (2009). Re-living dangerous memories: Online journaling to interrogate spaces of "otherness" in an educational administration program at a Midwestern university. Journal of Research on Leadership Education, 4(2), 1-2.

Gay, G. (2010). Culturally responsive teaching: Theory, research, and practice. New York, NY: Teachers College Press.

Gershon, W. S. (2010). Entertaining ideas and embodied knowledge: Musicians as public intellectuals. In J. A. Sandlin, B. D. Schultz, Burdick, \& J. Burdick(Eds.), The handbook of public pedagogy (pp. 628-638). New York, NY: Routledge.

Gershon, W. S. (2012). Sonic ethnography in practice: Students, sounds, and making sense of science. Anthropology News, 53(5), 5, 12.

Glesne, C. (2006). Becoming qualitative researchers: An introduction. Boston, MA: Allyn \& Bacon.

Gooden, M., \& Dantley, M. (2012). Centering race in a framework for leadership preparation. Journal of Research on Leadership Education, 7(2), 237-253.

Geurts, K. L. (2002). Culture and the senses: Bodily ways of knowing in an African community. Berkeley, CA: University of California Press.

Greene, M. (1988). The dialectic of freedom. New York, NY: Teachers College Press.

Greene, M. (2004). Curriculum and consciousness. In D. J. Flinders \& S. J. Thornton (Eds.), The curriculum studies reader (2nd ed.) (pp.135-147). New York, NY: Routledge.

Hartman, D., Gerteis, J., \& Croll, P. (2009). An empirical assessment of Whiteness theory: Hidden from how many? Social Problems, 56(3), 403424.

Hatch, A., \& Wisniewski, R. (1995). Life history and narrative. London, UK: The Falmer Press. 
Howes, D. (2003). Sensual relations: Engaging the senses in culture and social theory. Ann Abor, Ml: University of Michigan Press.

Howes, D. (2005). Empire of the senses: The sensual culture reader. Oxford, UK: Berg Press.

Josselson, R. (2003). Introduction. In R. Josselson, A. Lieblich, \& D. McAdams (Eds.), Up close and personal: The teaching and learning of narrative research (pp. 3-12). Washington, DC: American Psychological Association.

Kaak, P. A. (2011). Power-filled lessons for leadership educators from Paulo Freire. Journal of Leadership Education, 10(1), 132-144.

Kincheloe, J., \& Pinar, W. (Eds.) (1991). Curriculum as social psychoanalysis: The significance of place. Albany, NY: State University of New York Press.

Kridel, C. (2010). Encyclopedia of curriculum studies. Thousand Oaks, CA: Sage.

$\mathrm{Kim}, \mathrm{J}$. (2008). A romance with narrative inquiry: Toward an act of narrative theorizing. Curriculum and Teaching Dialogue, 10(1 \& 2), 251-267.

Langer, S. K. (1953). Feeling and form: A theory of art. New York, NY: Scribner.

Leavy, P. (2009). Method meets art: Arts-based research practice. New York, NY: The Guilford Press.

Lincoln, Y., \& Guba, E. (1985). Naturalistic inquiry. New York, NY: Sage.

Lindsey, R., Roberts, L., \& Campbelljones, F. (2005). The culturally proficient school: An implementation guide for school leaders. Thousand Oaks, CA: Corwin Press.

Malewski, E. (2009). Curriculum studies handbook: The next moment. New York, NY: Routledge.

Marshall, C., \& Anderson, A.L. (2008). Activist educators: Breaking past limits. New York, NY: Routledge.

Marshall, C., \& Oliva, M. (2010). Leadership for social justice: Making revolutions in education ( $2^{\text {nd }}$ ed.). Boston, MA: Allyn \& Bacon.

Marx, K., \& Engels, F. (1964). The German ideology. New York, NY: International Publishers.

Menon, R. (2010). Seductive aesthetics of postcolonialism. New York, NY: Hampton Press.

Merriam, S. B. (1998). Qualitative research and case study applications in education. San Francisco, CA: Jossey Bass.

Mezirow, J. (1990). Fostering critical reflection in adulthood: A guide to transformative and emancipatory learning. San Francisco, CA: JosseyBass. 
Miles M. B., Huberman A. M. (1984) Qualitative data analysis: A sourcebook of new methods. Newbury Park, CA: Sage.

Nieto, S. (2000). Affirming diversity: The sociopolitical context of multicultural education. New York, NY: Adison Wesley Longman.

Noddings, N. (1984). Caring: A feminine approach to ethics and moral education. Berkeley, CA: University of California Press.

Orfield, G., \& Lee, C. (2005). Why segregation matters: Poverty and educational inequality. Cambridge, MA: Civil Rights Project at Harvard University. Retrieved from http://escholarship.org/uc/item/4xr8z4wb

Pinar, W. F. (2011). What is curriculum theory? New York, NY: Routledge.

Pinar, W. F. (1988). Autobiography and the architecture of self. Journal of Curriculum Theorizing, 8(1), 7-35.

Ranciere, J. (2010). Dissensus: On politics and aesthetics. New York, NY: Continnum.

Schön, D. (1983) The reflective practitioner: How professionals think in action. San Francisco, CA: Basic Books.

Shoho, A. R., Barnett, B. G., \& Tooms, A. K. (2011). Examining the assistant principalship: New puzzles and perennial challenges for the $21^{\text {st }}$ century. Charlotte, NC: Information Age Publishing.

Skrla, L., McKenzie, K., \& Scheurich, J. (2009). Using equity audits to create equitable and excellent schools. Thousand Oaks, CA: Corwin Press.

Springgay, S. (2008). Body knowledge and curriculum: Pedagogies of touch in youth and visual culture. New York, NY: Peter Lang.

Terrell, R. D., \& Lindsey, R. B. (2009). Culturally proficient leadership: The personal journey begins within. Thousand Oaks, CA: Corwin Press.

Theoharis, G., \& Brooks, J. S. (2012). What every principal needs to know to create equitable and excellent schools. New York, NY: Teachers College Press.

Tooms, A. K., \& Boske, C. (Eds.) (2010). Building bridges: Connecting educational leadership and social justice to improve schools. Charlotte, NC: Information Age Publishing.

U.S. Department of Education (2012). New data from U.S. department of education highlights educational inequities around teacher experience, discipline and high school rigor. Retrieved from http://www.ed.gov/news/press-releases/new-data-us-departmenteducation-highlights-educational-inequities-around-teache

Weber, S. (1990). The teacher educator's experience: Cultural generativity and duality of commitment. Curriculum Inquiry, 20(2), 141-159. 


\section{Author Contact}

Christa Boske: boske@kent.edu

Kent State University, Foundations, Leadership and Administration, Educational Administration, 316-i White Hall, Kent, OH 44240, U.S.A. 